奖

MARX, ENGELS, AND MARXISMS

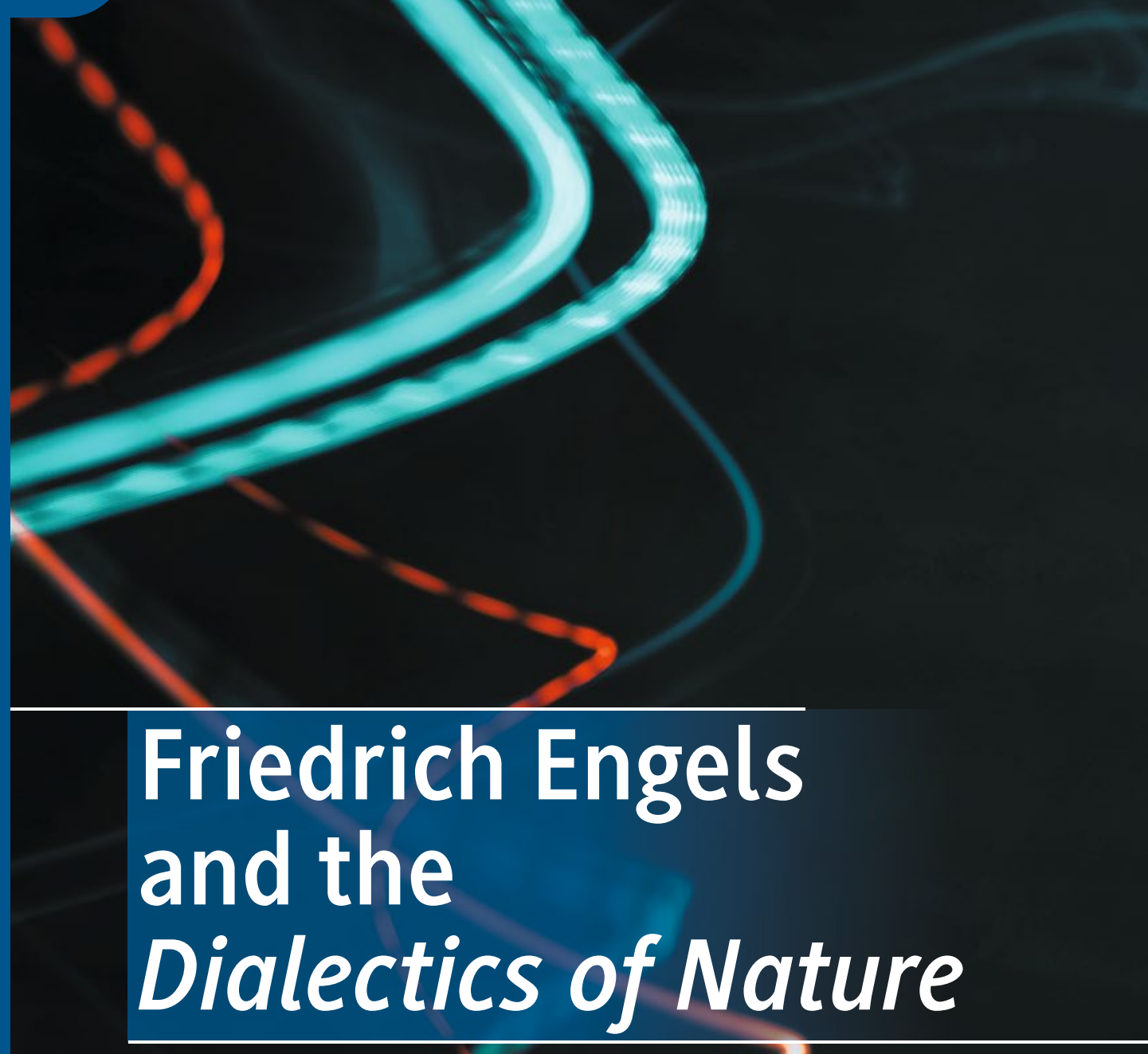

Kaan Kangal 
Kaan Kangal

Friedrich Engels and the Dialectics of Nature

palgrave macmillan 
Kaan Kangal

Nanjing University

Nanjing, Jiangsu, China

ISSN 2524-7123

Marx, Engels, and Marxisms

ISBN 978-3-030-34334-7

https://doi.org/10.1007/978-3-030-34335-4
ISSN 2524-7131 (electronic)

ISBN 978-3-030-34335-4 (eBook)

(C) The Editor(s) (if applicable) and The Author(s), under exclusive licence to Springer Nature Switzerland AG 2020

This work is subject to copyright. All rights are solely and exclusively licensed by the Publisher, whether the whole or part of the material is concerned, specifically the rights of translation, reprinting, reuse of illustrations, recitation, broadcasting, reproduction on microfilms or in any other physical way, and transmission or information storage and retrieval, electronic adaptation, computer software, or by similar or dissimilar methodology now known or hereafter developed.

The use of general descriptive names, registered names, trademarks, service marks, etc. in this publication does not imply, even in the absence of a specific statement, that such names are exempt from the relevant protective laws and regulations and therefore free for general use. The publisher, the authors and the editors are safe to assume that the advice and information in this book are believed to be true and accurate at the date of publication. Neither the publisher nor the authors or the editors give a warranty, expressed or implied, with respect to the material contained herein or for any errors or omissions that may have been made. The publisher remains neutral with regard to jurisdictional claims in published maps and institutional affiliations.

Cover illustration: (c) Mohd Azhari Bin Ibrahim / EyeEm / Getty Image

This Palgrave Macmillan imprint is published by the registered company Springer Nature Switzerland AG.

The registered company address is: Gewerbestrasse 11, 6330 Cham, Switzerland 


\section{Praise for Friedrich Engels and the Dialectics of Nature}

“This book gives a detailed analysis of Engels' Dialectics of Nature and the fullest and best account that I have seen of the controversies that have swirled around it and Engels' philosophy more generally. It covers debates in the English, German and Russian literature. Remarkably comprehensive. A unique and invaluable resource."

- Sean Sayers, Emeritus Professor of Philosophy, University of Kent, UK

"Why has a text on philosophy and the natural sciences written in the 19th century generated so much controversy for so many decades? Kaan Kangal surveys the battlefield in a thorough, lively and insightful way. He takes on those who have been there before him and puts forth his own fresh perspective on it all.”

-Helena Sheehan, Emeritus Professor, Dublin City University, Ireland

"Kaan Kangal's book is an indispensable resource for understanding and evaluating Frederick Engels' philosophy of nature, his views about dialectics, and their relation to Marx's ideas. The heart of the book is a deep exploration of Engels' intentions, arguments, ambiguities and contradictions, as expressed in his unfinished Dialectics of Nature, a 'book' assembled and reassembled by others. Especially valuable are Kangal's account of Engels' different, overlapping projects and his complex relationships with Hegel, Kant and Aristotle."

-Thomas Weston, Emeritus Professor of Philosophy, San Diego

State University, USA 


\section{Contents}

1 Introduction: Newe Engels-Lektüre 1 $\begin{array}{ll}\text { References } & 7\end{array}$

2 After Engels, After Marx 9 Marx, Engels and Authenticity 12

The Politics of Reading Engels $\quad 18$

Hermeneutic Concerns $\quad 24$

Author, Text and Reader 26

Structures of Argumentation $\quad 29$

References 38

3 The Origins of the Engels Debate 43

The Hegel Problem 45

Early Socialist Debates 46

The Lukács Controversy $\quad 52$

The Birth of Dialectics of Nature 56

Deborinites Versus Mechanists $\quad 60$

The Marx-Engels Problem 67

Summary $\quad 69$

References $\quad 79$

4 Dialectics of Nature Between Politics and Philosophy 93 Function of Theory 97

Role of Intellectuals 99 
xvi CONTENTS

Relevance of Philosophy 103

Marx's Unwritten 'Dialectics' and Engels' Project 108

Motives Behind Dialectics of Nature 111

References 115

5 Dialectics in Dialectics of Nature 121

General Premises and Goals 127

Hegel in Naturdialektik $\quad 132$

Dialectics 134

Engels' 'Determinations of Reflection' 136

The Aristotle-Hegel Alignment 139

Engels Against Kant 144

Metaphysics and Idealism 151

Plan 1878, Plan 1880 and Four Folders 165

$\begin{array}{ll}\text { References } & 177\end{array}$

6 Conclusion: What Is Dialectics of Nature? 183

Aristotle, Kant and Hegel 186

Engels in Dialogue with His Precursors 192

Engels in Dialogue with His Readers 198

The Torso 204

References 206

$\begin{array}{ll}\text { Index } & 207\end{array}$ 